EDITORIAL

\title{
Challenge in the Treatment of Children with Congenital Heart Disease: Reducing Waiting Time for Cardiac Surgery
}

\author{
Ana Flavia Malheiros Torbey ${ }^{(\mathbb{0}}$ and Aurea Grippa ${ }^{(\mathbb{}}$ \\ Universidade Federal Fluminense, Niterói, RJ - Brazil
}

Congenital heart disease is an important cause of mortality in the neonatal period. ${ }^{1}$ in Brazil, according to data from DATASUS from the period between 2012 and 2016, congenital heart disease is the third most common malformation in children younger than 28 days, with an estimated incidence of $1.3-1.7 \%$ and high mortality rate in this age range. They are also the third main cause of global mortality in the first 30 days of life, the main cause among congenital abnormalities. Therefore, 28,000 new cases per year are expected in Brazil., ${ }^{2,3}$

The outcomes of congenital heart disease can be grouped into spontaneous resolution of minor lesions, such as some interatrial or interventricular communications or persistent arterial duct; conditions that require repair procedures (interventional catheterizations or surgeries); and those cases that only palliative procedures can be performed due to anatomical and physiological features. Thus, approximately $20 \%$ of cases do not require surgery and resolve spontaneously, and nearly half of the other $80 \%(22,400$ children $)$ will require cardiac surgery in the first year of life. ${ }^{4,5}$

In the last four decades, advances in surgical and anesthetic techniques, adaptation of neonates to cardiac catheterization, in addition to improvements in postoperative follow-up have changed the natural history of congenital heart disease, as most of the patients did not reach adult life in the past., ${ }^{3,6}$ The early diagnosis of critical congenital heart disease, performed during prenatal care by fetal echocardiography, and neonatal screening by pulse oximetry have enabled the planning of appropriate

\section{Keywords}

Heart Defects, Congenital/surgery; Public Health; Health Services Accessibility; Public Policy. treatment, increase in survival in the neonatal period and consequent improvement in the prognosis. ${ }^{7}$

However, despite changes in the diagnosis and treatment of congenital heart disease, both prognosis and mortality may vary widely among the countries, due to poor access to healthcare services in developing countries, that show higher mortality rates compared with developed countries. ${ }^{8}$

In Brazil, a continental-size country, there is also inequality between its geographic regions, with treatment gaps of nearly $90 \%$ in the northern and northeastern regions. ${ }^{4,5,8}$ Today, there are 69 centers of the Brazilian Unified Health System (SUS) where pediatric cardiac surgery can be performed, according to data published by the Brazilian Ministry of Health, 2017. However, in $49 \%$ of the specialized services, the minimum predicted pediatric surgeries for congenital heart disease is not reached, with an annual average of 17 surgeries per year, which is far lower than the expected 120 surgeries/year per pediatric center. ${ }^{4}$

Therefore, one of the greatest challenges in the management of children with heart diseases is to provide adequate access of these patients to appropriate treatment and follow-up, be it cardiac surgery or interventional catheterization. Jesus et al. report the size of this challenge in the article entitled Fila de Espera para Tratamento de Pacientes com Cardiopatia Congênita: Retrato de um Centro de Referência Amazônico. ${ }^{9}$ In this report, the mean waiting time for elective hemodynamic procedures was $23.1 \pm 18.3$ months. Such long waiting time has severe consequences, as it leads to a delay in adequate treatment, worse prognosis, increased number of hospitalizations, and high morbidity and mortality rates. The authors also highlight another issue to be addressed - the poor access of this population to primary health care, for diagnosis of the diseases and referral to treatment, surgical or not. 
Recently, the Brazilian Ministry of Health, with the objective to expand the healthcare provided to children with heart diseases, approved a national action plan for children with congenital heart disease, the Plano Nacional de Assistência à Criança com Cardiopatia Congênita, aiming at establishing guidelines and actions that promote the access to diagnosis, treatment and rehabilitation of children and adolescents with congenital heart disease. ${ }^{10}$ Investments not only in reducing waiting time for surgical treatment, but also in providing access to appropriate care, since diagnosis in the prenatal period until treatment, could have an impact on morbidity and mortality in this children with congenital heart disease, with direct effects on children mortality rates, mainly in early neonatal period. ${ }^{11}$

Jesus et al., ${ }^{9}$ also draw attention to the fact that most of heart diseases diagnosed in the study population were potentially treatable by cardiac catheterization (65.2\%), such as persistent arterial duct, small interatrial communication, coarctation of the aorta and pulmonary valve stenosis. Therefore, to reduce the waiting time for cardiac surgery, the authors suggest the investment in percutaneous treatment, as it requires shorter hospitalization time, thereby promoting higher bed turnover rates in intensive care units and pediatric wards. Also, the authors discuss several strategies to improve health care for this group of patients, such as the development of specialized units and investments in diagnostic methods such as computed tomography angiography and magnetic resonance. ${ }^{8,9}$

Therefore, improvements in health care for heart disease children must be a priority. To this end, a combined effort of public power, health professionals and society is needed.

\section{References}

1. Van der Linde D, Konings EEM, Slager MA, Witsenburg M, Helbing WA, Takkenberg JJ, Roos-Hesselink JW. Birth Prevalence of Congenital Heart Disease. J Am Coll Cardiol. 2011;58(21):2241-7.

2. Brasil. Ministério da Saúde. DATASUS.[acwsso em 2019 abr 15]. Disponível em: http://tabnet.datasus.gov.br/cgi/tabcgi.exe?sinasc/cnv/ nvuf.def.

3. Bernier PL, Stefanescu A, Samoukovic G and Tchervenkov CI. The challenge of congenital heart disease worldwide: epidemiologic and demographic facts. Sem thorac cardiovasc surg. Pediatr Card Surg Annu. 2010;13(1):26-34.

4. Brasil. Ministério da Saúde. Governo federal lança plano para ampliar atendimento de crianças com cardiopatia congênita. [Acesso em 2019 jan 11]. Disponível em:http://portalarquivos2.saude.gov.br/images/pdf/2017/ julho/11/21.06_Cardiopatia\%20Congenita\%20pediatrica.pdf

5. Pinto Jr VC, Rodrigues LC, Muniz CR. Reflexions about formulation of politics for attention to cardiovascular pediatrics in Brazil. Braz J Cardiovasc Surg. 2009;24(1):73-80.

6. Khairy P, Ionescu-Ittu R, Mackie AS, Abrahamowicz M, Pilote L, Marelli AJ. Changing Mortality in Congenital Heart Disease. J Am Coll Cardiol. 2010; 56(14):1149-57.

7. Kemper AR. Lam WKK, Bocchini JA. The Success of State Newborn Screening Policies for Critical Congenital Heart Disease. JAMA. 2017; 318 (21): 2087-8.

8. Lopes SAVA, Guimarães ICB, Costa SFO, Acosta AX, Sandes KA, Mendes CMC. Mortalidade para Cardiopatias Congênitas e Fatores de Risco Associados em Recém-Nascidos. Um Estudo de Coorte. Arq Bras Cardiol. 2018; 111(5):666-73.

9. Jesus VS, Nascimento AM, Miranda RA, Lima JS, Tyll MAG, Veríssimo AOL. Fila de Espera para Tratamento de Pacientes com Cardiopatia Congênita: Retrato de um Centro de Referência Amazônico. Int J Cardiovasc Sci. 2018;31(4)374-82

10. Brasil. Ministério da Saúde. Portaria 1.727 de 11 de julho de 2017. Aprova o Plano Nacional de Assistência à Criança com Cardiopatia Congênita. [Acesso em 2019 jan 10]. Disponível em: http://bvsms.saude.gov.br/bvs/ saudelegis/gm/2017/prt1727_12_07_2017.html.

11. Salim TS, Soares GP, Klein CH, Oliveira GMM. Mortalidade por Doenças e Malformações do Aparelho Circulatório em Crianças no Estado do Rio de Janeiro. Arq Bras Cardiol. 2016; 106(6):464-73 